\title{
ANALISIS KINERJA INDUSTRI TEPUNG KELAPA PT. ROYAL COCONUT KELURAHAN SARONGSONG SATU KECAMATAN AIRMADIDI KABUPATEN MINAHASA UTARA
}

\author{
Margareta Risa Doppo \\ Tommy F. Lolowang \\ Lorraine W. Th. Sondak
}

\begin{abstract}
ABSRACT
This study aims to determine the Performance of Coconut Flour Industry in Kelurahan Sarongsong Satu Kecamatan Airmadidi Minahasa Utara Regency reviewed from Balanced Scorecard is a financial perspective, customer perspective, internal business process perspective and learning and growth perspective. This research was conducted at PT. Royal Coconut located in Kelurahan Sarongsong Satu Kecamatan Airmadidi Minahasa Utara Regency. This research will be conducted for 3 months from preparation until preparation of report, that is from February until month Mey 2017. Sources of data taken in this research are primary data and secondary data. Primary data is data that comes from the observation (observation) and interview (interview) with the leadership and a number of company employees. Secondary data is data obtained in the form of reports from other information sourced from literature and other information related to this writing. The method of analysis used in this research is Balanced Scorecard method that is financial perspective, customer perspective, internal business process perspective and learning and growth perspective. This research found that performance of Coconut Flour Industry PT. Royal Coconut Kelurahan Sarongsong One District Airmadidi Minahasa Utara Regency reviewed from Balanced Scorecad that financial perspective can be measured well and perfect for getting a profit every month.
\end{abstract}

Keywords: Analysis of Indusry Performance, Coconut Desicated, PT. Royal Coconut, Sarongsong One Urban Village, Airmadidi District, North Minahasa Regency

\begin{abstract}
ABSTRAK
Penelitian ini bertujuan untuk mengetahui Kinerja Industri Tepung Kelapa Di Kelurahan Sarongsong Satu Kecamatan Airmadidi Kabupaten Minahasa Utara ditinjau dari Balanced Scorecard yaitu prespektif keuangan, prespektif pelangggan, prespektif proses bisnis internal serta prespektif pembelajaran dan pertumbuhan. Penelitian ini dilakukan pada PT. Royal Coconut yang terletak di Kelurahan Sarongsong Satu Kecamatan Airmadidi Kabupaten Minahasa Utara. Penelitian ini akan dilaksanakan selama 3 bulan dari persiapan sampai penyusunan laporan, yaitu pada bulan February sampai bulan Mey 2017. Sumber data yang diambil dalam penelitian ini adalah data primer dan data sekunder. Data Primer yaitu data yang bersumber dari hasil pengamatan (observasi) dan wawancara (interview) dengan pimpinan dan sejumlah karyawan perusahaan. Data sekunder yaitu data yang diperoleh berupa laporan-laporan dari informasi lain yang bersumber dari literature dan informasi lain yang berhubungan dengan penulisan ini. Metode analisis yang digunakan dalam penelitian ini adalah metode Balanced Scorecard yaitu prespektif keuangan, prespektif pelanggan, prespektif proses bisnis internal dan prespektif pembelajaran dan pertumbuhan. Penelitian ini menemukan bahwa kinerja Industri Tepung Kelapa PT. Royal Coconut Kelurahan Sarongsong Satu Kecamatan Airmadidi Kabupaten Minahasa Utara ditinjau dari Balanced Scorecad yaitu prespektif keuangan sudah dapat diukur dengan baik dan sempurna karena mendapatkan keuntungan setiap bulan.
\end{abstract}

Kata kunci: Analisis Kinerja Industri, Tepung Kelapa, PT. Royal Coconut, Kelurahan Sarongsong Satu, Kecamatan Airmadidi, Kabupaten Minahasa Utara 


\section{PENDAHULUAN}

\section{Latar Belakang Masalah}

Indonesia merupakan negara tropis berbentuk kepulauan yang merupakan negara produsen kelapa di dunia. Bagi masyarakat Indonesia kelapa merupakan sumber pendapatan utama bagi petani serta kelapa memiliki berbagai manfaat bagi kehidupan, mulai dari buah, daun, batang sampai akarnya. Biasanya kelapa di olah/dibuat dalam beberapa olahan kelapa yaitu tepung kelapa, minyak goreng, virgin coconut oil dan masih banyak lagi hasil olahan dari kelapa. Sebagai produsen terbesar di dunia, kelapa di Indonesia menjadi ajang bisnis raksasa mulai dari pengadaan sarana produksi (bibit, pupuk, pestisida). Proses produksi, pengolahan produk kelapa (turunan dari daging, tempurung, sabut, kayu, lidi, dan nira). Serta aktivitas penunjangnya keuangan, irigasi, transportasi,

dan perdagangan.(Kemenperin,2008). Di Sulawesi Utara pengembangan dan pembangunan sektor pertanian sangatlah penting mengingat bahwa Sulawesi Utara mempunyai potensi sumberdaya alam yang besar ada pada sektor pertanian. Oleh sebab itu terjadinya perubahan harga terhadap komoditi produk turunan kelapa, akan mempengaruhi secara langsung tingkat kehidupan petani beserta seluruh keluarganya. Hasil produksi turunan kelapa dapat memberikan sumbangan devisa bagi negara produsen. Tabel.1 Luas areal produksi tepung kelapa sulut tahun 2014-2016.

\section{Tabel 1. Luas areal Produksi Kelapa} Sulut Tahun 2014-2016

\begin{tabular}{cccc}
\hline & 2014 & 2015 & 2016 \\
\hline Luas & 268.56 & 268.74 & 268.409 \\
(Ha) & 1 & 4 & \\
\hline Produksi & 278.89 & 278.76 & 278.511 \\
(Ton) & 2 & 1 & \\
\hline Sumber: Badan Pusat Statistik, & (Sulawesi \\
Utara), 2016 & &
\end{tabular}

Sulawesi Utara merupakan salah satu daerah produksi kelapa di Indonesia yang memiliki luas areal tanaman kelapa terbesar, sehingga daerah ini sering disebut daerah nyiur melambai. Pada tahun 2016 luas areal perkebunan kelapa di Sulawesi Utara sebesar 268.409 ha atau dengan presentasi sebesar $68,40 \%$. Produk turunan kelapa Sulawesi Utara mampu di pasarkan ke internasional karena kualitas yang dimiliki oleh produk olahan kelapa dan di minati oleh mancanegra, khususnya Belanda dan Amerika Serikat (Tatengkeng, 2011). Tersediahnya buah kelapa dalam jumlah yang cukup melimpah di Indonesia membuat pendirian industri berbasis komoditas ini cukup prespektif. Apalagi jika industry tersebut menerapkan teknologi pengolahan secara terpadu sehingga dari bahan baku kelapa dapat dibuat berbagai macam produk olahan secara sekaligus. Industry pengolahan tepung kelapa, rata-rata merupakan industry kecil dengan bahan baku utama adalah tempurung kelapa. Tempurung merupakan hasil saming (by product) buah kelapa. Hampir $60 \%$ butir kelapa yang dihasilkan di konsumsi dalam bentuk kelapa segar, di mana sebagian besar untuk memenuhi kebutuhan rumah tangga. Ini berarti tempurung sisa berada di sekitar pasar sebagai limbah besar (Mahmud2005). Ketersediaan bahan baku tempurung kelapa yang melimpah dan proses pengolahannya menjadi produk bentuk tepung yang sederhana menjadikan usaha ini cukup berkembang. Produk yang dihasilkan dari industi ini berupa tepung dengan ukuran mesin lebih dari 80 mesh.Tempurung kelapa memberikan nilai tambah apabila diproses menjadi tepung, arang atau arang aktif. Secara umum, utilitas yang digunakan dalam memproses tempurung kelapa menjadi bentuk dengan ukuran 80 mesh yaitu mesin diesel yang berguna untuk menggerakkan mesin crusher mill dan dibantu mesin genset penambah daya untuk menggerakkan panel-panel seperti motor dan blower. Pengukuran kinerja perusahaan bertujuan untuk mengetahui sejauh mana perkembangan perusahaan tersebut telah tercapai. Pengetahuan mengenai kondisi yang terjadi sekarang adalah dasar perusahaan untuk melakukan perbaikan dan melakukan langkahlangkah akan di ambil pada tahap berikutnya.Pengukuran kinerja perusahaan merupakan suatu alat manajemen yang penting. Di dalam menghadapi persaingan di pasar global, perusahaan harus selalu terpacu untuk meningkatkan kinerjanya secara terus menerus. Adanya suatu pengukuran kondisi proses bisnis 
perusahaan dapat diketahui Balanced Scorecard (BSC) yang merupakan konsep pengukuran yang diturunkan langsung dari strategi bisnis perusahaan perlu terus dipantau, karena akan mengarahkan karyawan terhadap faktor-faktor sukses kunci untuk membangun kesuksesan perusahaan. Untuk mencapai keberhasilan ini, perusahaan harus termotivasi untuk melakukan perbaikan yang berkelanjutan baik terhadap hasil pengukuran kinerja maupun tolok ukur kinerja itu sendiri. Tolak ukur kinerja yang dimaksud adalah key performance dalam BalancedScorecard (BSC). PT. Royal Coconut merupakan suatu perusahaan di bidang industri tepung kelapa (Dessiccated Coconut). Dalam melaksanakan aktivitas operasinya sebagai perusahaan industri tepung kelapa, maka perusahaan dari tahun ke tahun mengalami peningkatan kinerja perusahaan. Oleh karena itu untuk dapat menentukan kinerja, perusahaan dapat menerapkan Balanced Scorecard sebagai alat ukur berbasis strategis, seperti financial perpectice, internal proses business, prespective, customer prespective, dan learning growth. Keunggulan penerapan Balanced Scorecard adalah untuk dapat memberikan ukuran yang dapat dijadikan sebagai dasar dalam perbaikan strategis.Berdasarkan penjelasan diatas maka perlu untuk mengetahui penulusuran mengenai“"Analisis Kinerja Industri Tepung Kelapa di PT Royal Coconut Kelurahan Sarongsong Satu Kecamatan Airmadidi Kabupaten Minahasa Utara dengan menggunakan pendekatan BSC.

\section{Perumusan Masalah}

Bagaimana Kinerja Industri Tepung Kelapa di PT Royal Coconut Kelurahan Sarongsong Satu dengan menggunakan pendekatan Balanced Scorecard yaitu prespektif keuangan, prespektif pelanggan, prespektif proses bisnis internal serta prespektif pembelajaran dan pertumbuhan ?

\section{Tujuan Penelitian}

Untuk mengetahui Kinerja Industri Tepung Kelapa Di Kelurahan Sarongsong Satu Kecamatan Airmadidi Kabupaten Minahasa Utara ditinjau dari Balanced Scorecard yaitu prespektif keuangan, prespektif pelangggan, prespektif proses bisnis internal serta prespektif pembelajaran dan pertumbuhan.

\section{Manfaat Penelitian}

Penelitian ini diharapkan bermanfaat bagi peneliti terutama dalam menerapkan ilmu yang dipelajari. Bagi PT Royal Coconut khususnya PT Royal Coconut Airmadidi sebagai masukan yang dapat dipertimbangkan untuk mengetahui kinerja industri tepung kelapa ditinjau dari Balanced Scorecard yaitu prespektif keuangan, prespektif pelanggan, prespektif proses bisnis internal, serta prespektif pembelajaran dan pertumbuhan.

\section{METODOLOGI PENELITIAN}

\section{Waktu Dan Tempat Penelitian}

Penelitian ini dilakukan pada PT. Royal Coconut yang terletak di Kelurahan Sarongsong Satu Kecamatan Airmadidi Kabupaten Minahasa Utara. Penelitian ini akan dilaksanakan selama 3 bulan dari persiapan sampai penyusunan laporan, yaitu pada bulan February sampai bulan Mey 2017.

\section{Sumber Data}

Sumber data yang diambil dalam penelitian ini adalah data primer dan data sekunder.

1. Data Primer yaitu data yang bersumber dari hasil pengamatan (observasi) dan wawancara (interview) dengan pimpinan dan sejumlah karyawan perusahaan.

2. Data sekunder yaitu data yang diperoleh berupa laporan-laporan dari informasi lain yang bersumber dari literature dan informasi lain yang berhubungan dengan penulisan ini.

\section{Konsep Pengukuran Variabel}

Adapun variabel yang diukur dalam penelitian ini yaitu :

1. Rasio return On Investment diukur berdasarkan kemampuan dari modal diinvestasikan dalam keseluruhan aktiva untuk menghasilkan keuntungan bersih pada PT Royal Coconut Airmadidi. Rasio return on investment adalah perbandingan antara eat dengan total aktiva yang dinyatakan dalam presentase $(\%)$. 
a. Eat adalah laba bersih setelah pajak pendapatan, HPP, biaya, pajak $10 \%$ yang dinyatakan dalam rupiah (Rp)

b. Total Aktiva adalah semua kekayaan yang dimiliki PT Royal Coconut Airmadidi yang terdiri dari biaya pemasran, biaya adm umum, biaya produksi, laba kotor, laba sebelum pajak, pajak 10\% dan laba setelah pajak yang dinyatakan dalam (Rp)

2. Rasio Profit Margin diukur berdasarkan keemampuan perusahaan untuk menghasilkan keuntungan dibandingkan dengan penjualan yang dicapai di PT Royal Coconut Airmadidi ddan dinyatakan dalam presentase $(\%)$.

a. Eat adalah laba bersih setelah pajak pendapatan, HPP, biaya, pajak $10 \%$ yang dinyatakan dalam rupiah (Rp)

b. Penjualan adalah pendapatan operasional yang di dapat dari penjualan tepung kelapa serta pendapatan lain-lain yang mencakup pendapatan kopra, dan pendapatan paring yang dinyatakan dlam (Rp).

3. Pertumbuhan pelanggan yaitu perbandingan jumlah pelanggan periode sekarang dikurangi jumlah pelanggan periode lalu dibagi dengan periode lalu, dinyatakan dalam presentase (\%).

4. Manufacturing Cycle Efficiency (MCE), diukur dengan waktu yang diperlukan karyawan dalam menyelesaikan proses transaksi menurut standar PT. Royal Coconut Airmadidi yang dinyatakan dalam menit.

5. Produktivitas karyawan yaitu perbandingan antara laba operasional, dengan jumlah karyawan periode bersangkutan, dinyatakan dalam rupiah (Rp).

6. Retensi karyawan yaitu perbandingan antara jumlah karyawan yang keluar dengan jumlah karyawan, dinyatakan dalam presentase $(\%)$.

\section{Metode Analisis Data}

Metode analisis yang digunakan dalam penelitian ini adalah metode Balanced Scorecard yaitu prespektif keuangan, prespektif pelanggan, prespektif proses bisnis internal dan prespektif pembelajaran dan pertumbuhan.

\section{Analisis Kinerja Prespektif Keuangan}

Penilaian kinerja pada prespektif keuangan menggunakan analisis rasio keuangan yang menggunakan ROI, dan Net Profit Margin.

- ROI (Return On Investment)
Tingkat pengembalian investasi dan pendapatan operasi atau yang biasa disebut dengan ROI yaitu rasio yang digunakan untuk mengukur kemampuan dari modal yang diinvestasikan dalam keseluruhan aktiva untuk menghasilkan laba bersih. ROI dapat dikatakan baik jika ratarata industrinya sebesar 9,8\% (Keown, 2008).

- Profit Margin

Profit margin digunakan untuk melihat besar kecilnya laba usaha dalam hubungannya dengan penjualan untuk mengetahui efisiensi perusahaan. Profit margin dikatakan baik jika rata-rata nilainya adalah sebesar $8,3 \%$ (Keown,2008). Semakin tinggi nilai profit margin berarti semakin baik, karena dianggap kemampuan perusahaan dalam mendapatkan laba cukup tinggi.

Analisis prespektif keuangan menggunakan rasio :

a. Rasio ROI (Return On Investement)

$$
\text { ROI }=\frac{\text { EAT }}{\text { TotalAktiva }} \times 100 \%
$$

b. Rasio Profit Margin

$$
\text { Profit Margin }=\frac{\text { EAT }}{\text { Penjualan }} \times 100 \%
$$

\section{Analisis Kinerja Prespektif Pelanggan}

- Prespektif Pelanggan

Pertumbuhan pelanggan adalah untuk mengukur tingkat pertumbuhan pelanggan dengan membandingkan jumlah pelanggan anggota periode sekarang dikurangi dengan jumlah pelanggan anggota periode lalu di bagi dengan pelanggan anggota periode lalu yang dinyatakan dalam presentase.

Pertumbuhan Pelanggan

$=\frac{\text { Jumlah pelanggan periode sekarang }}{\text { Jumlah pelanggan periode lalu }} \times 100 \%$

\section{Analisis Kinerja Prespektif Bisnis Internal}

Tolak ukur yang digunakan dalam analisis ini adalah Manufacturing Cycle Efficiency ( MCE). Jika dalam perhitungan MCE menghasilkan angka sebesar 1, maka usaha untuk mengurangi waktu tidak bernilai tambah menjadi nol, telah berhasil. Jadi, idealnya suatu perusahaan harus berusaha mengeliminasi aktivitas tidak bernilai tambah dengan cara mengurangi waktu tidak bernilai tambah menjadi nol. MCE yang sempurna atau ideal adalah sebesar 1 (Jayanto, 2009).

$M C E=\frac{\text { Waktu pengolahan (menit) }}{\text { Waktu penyelesaian (menit) }}$ 


\section{Analisis Kinerja Prespektif Pertumbuhan dan Pembelajaran}

a. Produktivitas karyawan

pengukuran kinerja pada prespektif ini adalah membandingkan keluaran yang dihasilkan oleh para pekerja dengan jumlah pekerja yang dikerahkan untuk menghasilkan keluaran tersebut.

Tingkat produktivitas karyawan $=\frac{\text { Laba Operasional }}{\text { Jumlah Karyawan }}$

b. Tingkat retensi karyawan

Pengukuran kinerja pada prespektif ini mempertahankan selama mungkin para karyawan yang diminati perusahaan karena mereka merupakan modal intelektual khusus organisasi dan merupakan aktiva non keuangan yang bernilai bagi perusahaan.

Tingkat retensi karyawan $\frac{\text { Jumlah karyawan yang keluar }}{\text { Jumlah karyawan }}$ $\times 100 \%$

\section{GAMBARAN UMUM PT. ROYAL COCONUT}

\section{Sejarah Singkat PT. Royal Coconut Airmadidi}

PT. Royal Coconut didirikan pada tanggal 18 Maret 2007 Oleh Bapak Jefry Jacom, keluarga Jacom di Sulawesi Utara Kabupaten Minahasa Utara. PT. Royal Coconut beralamat di Kelurahan Sarongsong Satu Kecamatan Airmadidi Kabupaten Minahas Utara, Sulawesi Utara, Indonesia. Kantor Pusat berada di Jl. Lodan Raya 02 Blok T 01-02 Lodan Center, Jakarta Utara, Indonesia yang juga merupakan kantor pemasaran dengan pimpinan Mr. Riflex Manderos. PT. Royal Coconut khusus memproduksi "Desiccated Coconut" yang disebut juga tepung kelapa. Negara tujuan pemasaran produk ini adalah negara-negara Eropa Barat dan Timur, dan sebagiaan negara-negara di Afrika. Sasaran utama perdagangan adalah $100 \%$ export.

\section{Visi Dan Misi Perusahaan}

PT. Royal Coconut telah menerapkan Rencana Kerja Jaminan Mutu lewat penggunaan suatu sistem keamanan pangan HACCP $($ Hazard Analysis And Critical Control Point) atau Analisis Bahaya dan Pengendalian Titik Kritis. Sistem HACCP yang berbasis ilmu pengetahuan dan sistematis, mengidentifikasi bahaya spesifik dan tindakan control untuk menjamin keamanan makanan. HACCP adalah alat untuk menilai bahaya spesifik dan menetapkan sistem kontrol yang fokus pada pencegahan dari pada mengandalakan pengujian pada produk akhir. Sistem HACCP mampu mengakomodasi perubahan, seperti kemajuan dalam desain peralatan, pengolahan prosedur atau perkembangan teknologi.

Rencana Kerja Jaminan Mutu:

1. Tujuan ditetapkan HACCP di PT. Royal Coconut untuk memproduksi desiccated coconut yang berdampak pada kualitas dan kuantitas produknya yang aman dan higienis untuk konsumsi manusia serta dapat berkompetitif di pasar global.

2. Sasaran mutu zero defect di PT. Royal Coconut memberikan tingkat risiko yang kecil bagi perusahaan maupun konsumen dengan mendorong tingkat ketelitian dan kompetensi bersama untuk memenuhi standard mutu nasioanal maupun internasional.

3. Manajemen dan karyawan bertekad mewujudkan HACCP sebagai budaya kerja dilingkungan pabril PT. Royal Coconut.

\section{Kegiatan Manajemen}

Dalam menjalankan usahanya perusahaan dipimpin oleh seorang direktur sebagai pemegang kekuasaan tunggal dalam perusahaan. Direktur bertanggung jawab dalam setiap aktivitas perusahaan, baik dalam menerbitkan kebijakan-kebijakan perusahaan; memilih, menetapkan, mengawasi tugas dari karyawan dan kepala bagian (manajer); menyetujui anggaran tahunan perusahaan; dan menyampaikan laporan kepada pemegang saham atas kinerja perusahaan. PT. Royal Coconut Airmadidi memiliki 354 orang karyawan yang memiliki 3 waktu shift kerja, yaitu shift pagi (jam $6 \mathrm{~s} / \mathrm{d} 2$ siang) shift siang (jam $2 \mathrm{~s} / \mathrm{d} 10$ malam) dan shift malam (jam $10 \mathrm{~s} / \mathrm{d}$ jam 6 pagi). Dalam sekali produksi biasanya menghabiskan waktu 20 jam (jam 6 pagi s/d jam 2 malam), ini pun jika tidak ada kendala seperti kerusakan pada alat produksi. Perusahaan perlu menyusun struktur organisasi agar dapat membantu pencapaian tujuan perusahaan. Dengan adanya struktur organisasi, fungsi dan kedudukan dari masingmasing karyawan yang ada dalam perusahaan 
dapat terlihat sehingga masing-masing karyawan dapat menjalankan tugas dan fungsinya. Setiap anggota organisasi harus mengetahui dari siapa dia menerima perintah dan kepada siapa ia harus bertanggung jawab atas semua tugas yang diterimanya.

\section{Kegiatan Pemasaran}

Sejak awal didirikannya perusahaan, PT. Royal Coconut telah memasarkan produknya ke luar negeri seperti Uni Emirate Arab, Dubai, Amerika Serikat, Belanda, Jerman, Rusia dan Turki. Perusahaan berusaha menarik konsumen dengan menawarkan kualitas terbaik dari produk yang dihasilkan.

\section{Proses Produksi}

Pada perusahan manufaktur atau pabrikan, proses produksi merupakan bagian yang sangat penting. Karena apabila kegiatan ini tidak dijalankan dengan baik, maka produk yang dihasilkan akan memiliki kualitas yang tidak baik pula. Untuk itu manajer produksi dituntut untuk dapat mengatur tahapan proses produksi dengan baik yang merupakan rangkaian kegiatan yang dilaksanakan oleh tenaga kerja dan mesin. Proses produksi pada PT. Royal Coconut menggunakan bahan baku utama yaitu kelapa. Kelapa merupakan satu-satunya bahan baku yang dibutuhkan dalam proses produksi, karena yang akan dihasilkan adalah desiccated coconut atau biasa disebut tepung kelapa. Berikut disajikan dalam gambar proses produksi produk pada PT. Royal Coconut dapat dilihat pada gambar 1.

\section{Kegiatan Personalia}

Manajemen personalia atau manajemen sumber daya manusia merupakan fungsi dari manajemen yang berhubungan dengan manusia khususnya bagaimana menjalin kerjasama dalam mengembangkan dan menumbuhkan berbagai kebijaksanaan dalam mempengaruhi organisasi maupun dalam membantu para pimpinan untuk mengelolah sumber daya manusia yang dimiliki perusahaan. Pada dasarnya kunci keberhasilan perusahaan dalam mencapai tujuan terletak pada unsur manusia. Karena manusia merupakan perencana dan pelaksana untuk setiap kegiatan perusahaan.

\section{Gambar 1.}

\section{Proses Produksi pada PT. Royal Coconut}

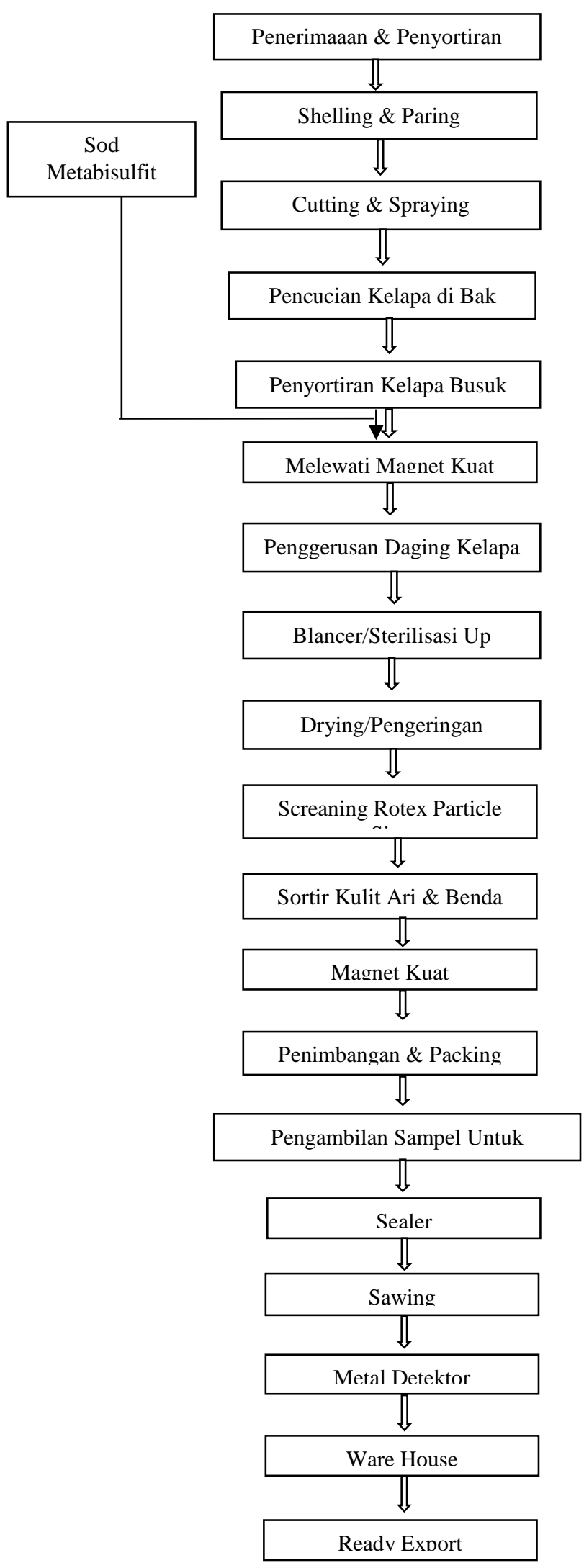




\section{HASIL DAN PEMBAHASAN}

Penelitian ini bertujuan untuk mengetahui Kinerja Industri Tepung Kelapa ditinjau dari Balanced Scorecard yang meliputi empat prespektif yaitu prespektif keuangan, prespektif pelanggan, prespektif, bisnis internal serta prespektif pembelajaran dan pertumbuhan.

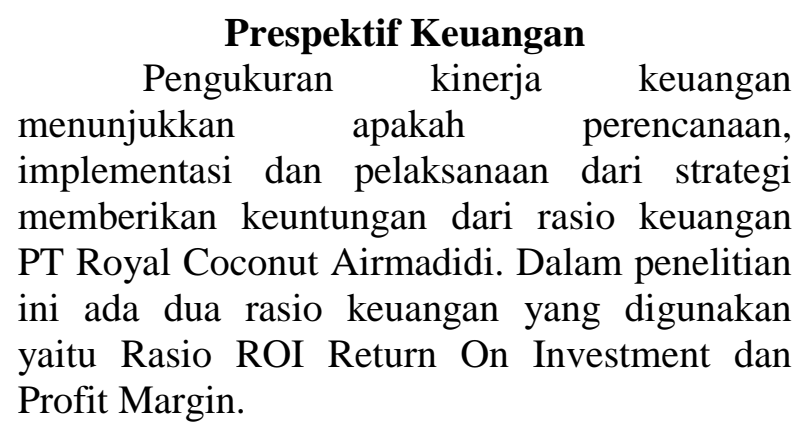

\section{Rasio Return On Investment}

Return on investment atau biasa disebut ROI, lebih dikenal dengan laba atas investasi. Roi merupakan ukuran atau indeks yang menunjukkan seberapa besar laba yang di dapat atas investasi yang telah ditanam pada perusahaan. Dengan kata lain seberapa besar investasi yang telah ditanam dapat dikembalikan menjadi keuntungan atau laba. Dan untuk mengetahui keuntungan yang di dapat dari Rasio Return on investment sebelumnya dilihat dari total pembelian dan biaya produksi tepung kelapa, kopra, dan paring yang di sajikan pada Tabel 3 dan Tabel 4 serta pada Tabel 5 terdapat biaya produksi tepung kelapa untuk bulan September-November 2016. Dan keuntungan yang di dapat dari rasio return on investment dapat dilihat pada lampiran keuangan. Tabel 2 dapat dilihat bahwa $20 \%$ dari berat kelapa adalah air dan air itu di buang. Perusahaan tidak menjual atau mengelola air kelapa menjadi produk sampingan. Untuk itu dalam kegiatan produksi crushing plant kelapa yang di beli dikurangkan dengan berat air sebesar 20\%. Memproduksi tepung kelapa selama bulan september hingga november menunjukkan angka presentase sebesar 50\% atas bahan baku yang di olah untuk menghasilkan tepung kelapa. Sedangkan produk sampingan yang dihasilkan sebesar $15 \%$ untuk paring dan $15 \%$ untuk kopra dari pengolahan bahan baku yang tidak dapat digunakan dalam pembuatan

Pembelian bahan baku kelapa yang berkisar Rp. 200/Kg. 20\% dari kelapa adalah air dan air itu di buang. Jika di hitung 20\% dari harga per-Kg kelapa adalah Rp. 400.- jadi berat air dari bulan September-November adalah Rp. $3.832721 \mathrm{Kg}$. maka air itu buang maka biaya yang dirugikan perusahaan adalah Rp. 7.663.440.880,- terlihat pada Tabel 3. karna perusahaan tidak memperlakukan air kelapa untuk dijual atau diolah atau menjadi produk sampingan lainnya. Tabel 4. Biaya produksi selama bulan September, Oktober dan November tahun 2016 ini adalah semua pengeluaran ekonomis yang harus dikeluarkan untuk memproduksi suatu produk tepung kelapa. Biaya produksi ialah pengeluaran yang dilakukan perusahaan dan bahan baku yang akan digunakan untuk menghasilkan suatu produk. Menyajikan data bahwa produk yang dihasilkan oleh perusahan untuk bulan September sampai dengan November tahun 2016 adalah Tepung Kelapa 9.579.300Kg, Kopra $2.873 .791 \mathrm{Kg}$ dan Paring 2.873.389Kg. Tabel 5. Biaya produksi tepung kelapa menyajikan data alokasi keseluruhan biaya produksi untuk bulan September, Oktober, November 2016 pada produk tepung kelapa sebesar 6.937.005.050.00. Berdasarkan perhitungan total biaya produksi tersebut, dapat dihitung keuntungan yang diperoleh PT. Royal Coconut Airmadidi untuk penjualan tepung kelapa selama 3 bulan.

Tabel 2. Total Pembelian September, Oktober dan November 2016

\begin{tabular}{ccccc}
\hline $\begin{array}{c}\text { Kegiatan } \\
\text { Produksi }\end{array}$ & September $(\mathbf{K g})$ & Oktober $(\mathbf{K g})$ & Novebe $(\mathbf{K g})$ & Total $(\mathbf{K g})$ \\
\hline Kelapa & 6.432 .904 & 5.473 .059 & 7.252 .639 & 19.158 .602 \\
Air & 1.286 .581 & 1.094 .612 & 1.450 .428 & 3.831 .621 \\
Crushing Plant & 5.146 .323 & 4.378 .447 & 5.802 .111 & 15.326 .881 \\
\hline
\end{tabular}

Sumber : PT. Royal Coconut Airmadidi,2016 
Tabel 3. Air Kelapa

\begin{tabular}{lllc}
\hline Bulan & Air Kelapa $($ Kg) & Harga Per Kg & Jumlah \\
\hline September & 1.286 .581 & Rp2.000,00 & Rp2.573.162.000,00 \\
Oktober & 1.094 .612 & Rp2.000,00 & Rp2.189.224.000,00 \\
November & 1.450 .528 & Rp2.000,00 & Rp2.901.056.000,00 \\
Total & 3.831 .721 & & Rp7.663.442.000,00 \\
\hline
\end{tabular}

Sumber : Data Hasil Olahan

Tabel 4. Biaya Produksi September, Oktober dan November 2016

\begin{tabular}{lllll}
\hline Kegiatan Produksi & September $(\mathbf{K g})$ & Oktober $(\mathbf{K g})$ & November $(\mathbf{K g})$ & Total $(\mathbf{K g})$ \\
\hline Tepung Kelapa & 3.216 .452 & 2.736 .529 & 3.626 .319 & 9.579 .300 \\
Kopra & 964.936 & 820.960 & 1.087 .895 & 2.873 .791 \\
Paring & 964.935 & 820.959 & 1.087 .895 & 2.873 .789 \\
\hline
\end{tabular}

Sumber : PT.Royal Coconut Airmadidi, 2016

Table 5. Biaya Produksi Tepung Kelapa September Oktober November 2016.

\begin{tabular}{|c|c|c|c|c|}
\hline Jenis Biaya & September $(\mathrm{Rp})$ & Oktober (Rp) & November (Rp) & Jumlah \\
\hline Biaya Bahan Baku & $1,929,876,200$ & $1,641,921,700$ & $2,175,796,700$ & $5,747,594,600$ \\
\hline Biaya Tenaga Kerja & $263,527,080$ & $259,015,252$ & $344,494,778$ & $867,037,110$ \\
\hline \multicolumn{5}{|l|}{ Biaya Overhead Pabrik: } \\
\hline Biaya Bahan Bakar & $23,407,780$ & $23,407,780$ & $23,407,780$ & $70,223,340$ \\
\hline Biaya Angkut & $4,500,000$ & $4,500,000$ & $4,500,000$ & $13,500,000$ \\
\hline BiayaPenyusutanGedung & $28,000,000$ & $28,000,000$ & $28,000,000$ & $84,000,000$ \\
\hline Biaya Listrik & $16,800,000$ & $16,800,000$ & $16,800,000$ & $50,400,000$ \\
\hline \multicolumn{5}{|l|}{ Penyusutan Mesin dan } \\
\hline Peralatan & $34,750,000$ & $34,750,000$ & $34,750,000$ & $104,250,000$ \\
\hline Total Biaya Produksi & $2,300,861,06$ & $2,008,394,73$ & $2627,749,25$ & $6.937,005,05$ \\
\hline
\end{tabular}

Tabel 6. Penerimaan biaya dan keuntungan produk tepung kelapa berdasarkan data hasil produksi dan biaya produksi tepung kelapa. Dimana produksi tepung kelapa selama bulan September sampai November 2016 di PT Royal Coconut Airmadidi produksi tepung kelapa selama 3 bulan dengan total 9.579 .300 atau 9,5 ton. Dan harga jual tepung kelapa per kg Rp. 8.880 hasil Rp. 85.064.184.000 dikurangi dengan biaya-biaya yang termasuk dalam produksi tepung kelapa $\mathrm{Rp}$. 6.937.007.050 jadi keuntungan yang didapat dalam hasil penjualan tepung kelapa $\mathrm{Rp}$. 78.127.176.950 sangat baik karena perusahaan mendapatkan keuntungan yang dihasilkan dari keuntungan produk tepung kelapa. Penerimaan dan biaya produksi kopra selama bulan September-November Menyajikan data biaya produksi Kopra dengan perhitungan keuntungan atas kopra berdasarkan data hasil produk dan biaya produksi dengan total biaya produksi selama bulan September-November Rp. 5.831.266.600. PT Royal Coconut mengelolah produk sampingan yaitu kopra. Kopra adalah daging buah kelapa yang dikeringkan. Dan kopra ini merupakan produk turunan kelapa yang sangat penting. Biaya-biaya yang dikeluarkan PT Royal Coconut terdiri atas beban biaya bahan baku, beban biaya tenaga kerja, beban biaya bahan bakar, dan beban biaya angkut pengeluaran tersebut dikatakan baik dikarenakan keuntungan yang didapat dari hasil penjualan kopra mengalami kenaikan dengan harga jual kopra Rp. 7000,-/kg dapat dilihat pada Tabel 7 dan Tabel $8 . \quad$ Tabel 8. Penerimaan biaya dan keuntungan produk kopra selama bulan September sampai November menunjukkan bahwa perhitungan keuntungan yang di dapat dari penjualan kopra berdasarkan data hasil produk dan biaya produksi selama bulan September-November produksi kopra selama 3 bulan $2.873 .791 \mathrm{Kg}$ 
atau sekitar 2,8 ton dengan harga jual $\mathrm{Rp}$. 7000,-Kg total $\mathrm{Rp}, 20.116 .537 .000$ dikurangi dengan total biaya produksi selama 3 bulan Rp. 5.831.266.600 dan keuntungan hasil penjualan yang di dapat dari PT. Royal Coconut Airmadidi mendapatkan keuntungan dari penjualan kopra dan dikatakan baik karena perusahaan mendapatkan keuntungan. Kopra sebagai produk sampingan dari hasil proses produksi tepung kelapa yang tidak dipakai dan masih bisa bermanfaat sebagai produk sampingan. Ini dinilai sebagai potensi produk sampingan bagi perusahaan yang dapat menghasilkan pendapatan di luar usaha (Other Income).

Tabel 6. Penerimaan Biaya dan Keuntungan Produk Tepung Kelapa Sept-Nov 2016.

\section{(a). Produksi}

Produksi Tepung Kelapa (3Bulan)

9.579.300

(b). Biaya

Biaya Produksi Tepung Kelapa (3 Bulan)

Biaya Bahan Baku

Biaya Tenaga Kerja

Biaya Overhead Pabrik :

Biaya Penyusutan Gedung

Biaya Listrik Dan Air

Biaya Bahan Bakar

Biaya Ankgkut

Biaya Penyusutan Mesin dan Peralatan

Total Biaya Produksi Tepung Kelapa (3Bulan)

c). Keuntungan

Keuntungan Hasil Penjualan Untuk Tepung

Kelapa

(Keterangan : Harga Jual Tepung Kelapa : Rp. 8.880,-/Kg
Harga Jual Tepung Kelapa

8.880,-/Kg Rp. 85.064.184.000

Rp.

5.747.596.600

867.037.110

84.000 .000

50.400 .000

70.223 .340

13.500 .000

104.250 .000

Rp. 6.937.007.050

Rp.78.127.176.950

Sumber : Data Hasil Olahan

Tabel 7. Biaya Produksi Kopra selama bulan September- November Tahun 2016.

\begin{tabular}{lllll}
\hline Jenis Biaya & September(Rp) & Oktober $(\mathbf{R p})$ & November (Rp) & Jumlah $(\mathbf{R p})$ \\
\hline Biaya Bahan Baku & 1.929 .866 .200 & 1.641 .913 .700 & 2.175 .786 .700 & 5.747 .566 .600 \\
Biaya Tenaga Kerja & 19.000 .000 & 19.000 .000 & 19.000 .000 & 57.000 .000 \\
BiayaOverheadPabrik & & & & - \\
Biaya Bahan Bakar & 7.400 .000 & 7.400 .000 & 7.400 .000 & 22.200 .000 \\
Biaya Angkut & 1.500 .000 & 1.500 .000 & 1.500 .000 & 4.500 .000 \\
Total Biaya Produksi & 1.957 .766 .200 & 1.669 .813 .700 & 2.203 .686 .700 & 5.831 .266 .600
\end{tabular}

Sumber : Data Hasil Olahan 


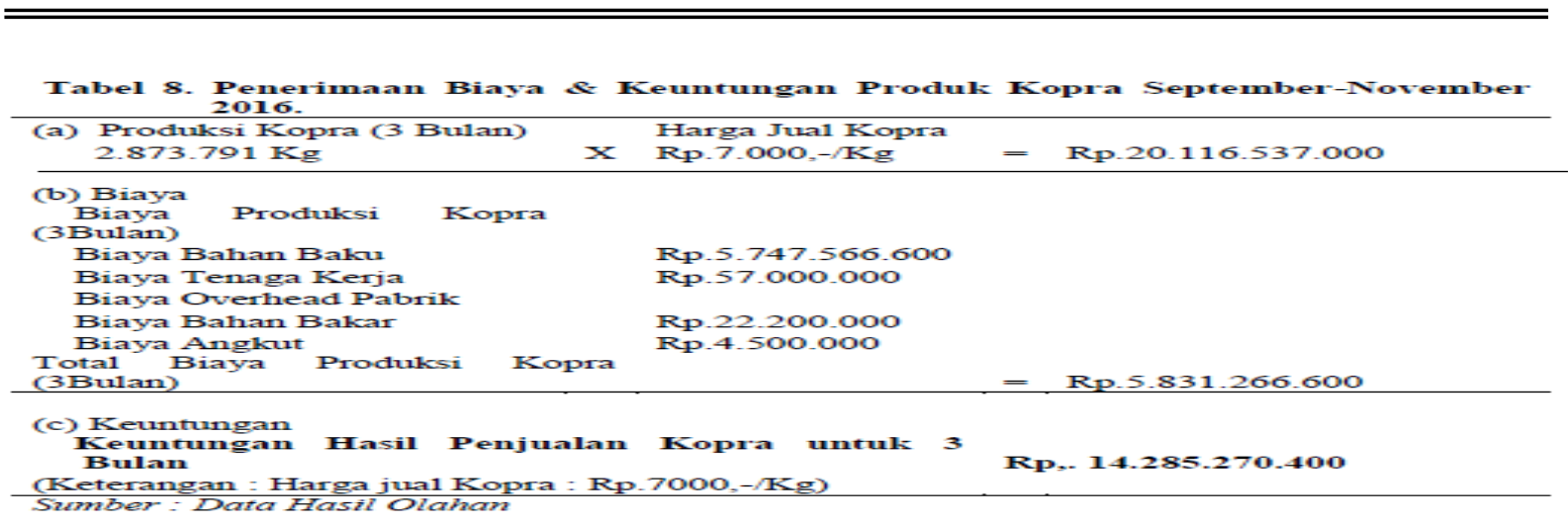

Tabel 9. Biaya Produksi Paring September-November tahun 2016.

\begin{tabular}{lcccc}
\hline \multicolumn{1}{c}{ Jenis Biaya } & $\begin{array}{c}\text { September } \\
(\mathbf{R p})\end{array}$ & Oktober (Rp) & $\begin{array}{c}\text { November } \\
(\mathbf{R p})\end{array}$ & Jumlah (Rp) \\
\hline Biaya Bahan Baku & 1.929 .876 .200 & 1.641 .921 .700 & 2.175 .796 .700 & 5.747 .594 .600 \\
BiayaTenaga Kerja & 19.000 .000 & 19.000 .000 & 19.000 .000 & 57.000 .000 \\
Biay Overhead & & & & - \\
Pabrik: & & & \\
Biaya Depresiasi & 2.700 .000 & 2.700 .000 & 2.700 .000 & 8.100 .000 \\
Biaya Listrik Dan Air & 4.680 .000 & 4.680 .000 & 4.680 .000 & 14.040 .000 \\
Biaya Bahan Bakar & 6.660 .000 & 6.660 .000 & 6.660 .000 & 19.980 .000 \\
Biaya Angkut & 1.500 .000 & 1.500 .000 & 1.500 .000 & 4.500 .000 \\
Total Biaya Produksi & 1.964 .416 .200 & 1.676 .461 .700 & 2.210 .336 .700 & 5.851 .214 .600 \\
\hline Sumber - Data Hasil Olahan & & &
\end{tabular}

Penerimaan dan biaya produksi paring menyajikan data bahwa total biaya produksi untuk bulan September, Oktober dan November tahun 2016 adalah sebesar Rp. 5.851.214.600,00 dengan biaya bahan baku Rp. 5.747.594.600 artinya total biaya produksi mengalami keuntungan yang dihasilkan dari penjualan kopra pada PT. Royal Coconut Airmadidi sehingga dikatakan baik karena mengalami keuntungan. Tabel 10. Penerimaan biaya dan keuntungan paring selama bulan September-November 2016 adalah sebesar Rp.5.851.214.600 yang di dapat dari produksi paring $2.873 .389 \mathrm{Kg}$ atau 2,8 ton dengan harga jual kopra Rp.6000,-/Kg dengan total Rp. 17.242.734.000 dan keuntungan yang di dapat dari hasil panjualan paring untuk 3 bulan adalah Rp. 11.391.591.400. PT. Royal Coconut Airmadidi mendapatkan keuntungan dari penjualan paring dan dikatakan baik karena mendapatkan keuntungan. Penerimaan dan biaya produksi produk paring pada Tabel 11 menyajikan data alokasi keseluruhan biaya produksi untuk bulan September-November 2016 pada produk Tepung Kelapa, Paring dan Kopra sebesar Rp. 6.748.755.050 dan produk paring sebesar Rp. 5.851.214.600 dan Kopra sebesar Rp. 5.831.266.600 berdasarkan perhitungan total biaya produksi tersebut, dapat dihitung keuntungan yang diperoleh PT. Royal Coconut Airmadidi untuk penjualan kopra dan paring selama 3 bulan.

\section{Rasio Profit Margin}

Rasio profit margin disebut juga dengan rasio pendapatan terhadap penjualan. Laba bersih dibagi penjualan bersih. Rasio ini menggambarkan besar laba bersih yang diperoleh perusahaan pada penjualan yang dilakukan. Tabel 12 Rasio Profit Margin di bulan Sept - Nov 2016 pada PT. Royal Coconut Airmadidi laba setelah pajak Rp. 33.891.361.606.80 dibagi dengan penjualan. Pendapatan operasional atau keuntungan yang didapat dari penjualan tepung kelapa dan pendapatan kopra serta paring sebesar Rp. 122.423.455.000 dengan persen 27,68\%. Artinya, untuk setiap 1 rupiah pendapatan perusahaan, perusahaan harus membayar beban usaha sebesar 0,27,68\% rupiah dari $(27,68 \%)$. Presentase Profit Margin ini dapat dijadikan sebagai indicator kesehatan suatu perusahaan. 
Jika presentase Profit marginnya rendah, artinya beban penjualan perusahaan tinggi sehingga menyebabkan Laba kotornya rendah.

Perusahaan perlu menerapkan strategi bisnis baru jika Profit Margin-nya di bawah angka 50\%. Berdasarkan hasil laba rugi kinerja PT.
Royal Coconut Airmadidi dari prespektif keuangan, dilihat dari rasio profit margin pada bulan Sept- Nov 2016. Laba kotor yang di dapat tinggi yaitu Rp. 72.635.235.350 maka dilihat dari bisnis yang dijalankan sangat efisien karna mendapatkan keuntungan Rp. $27,68 \%$.

Tabel 10. Penerimaan Biaya \& Keuntungan Produk Paring Bulan September- November 2016.

\begin{tabular}{|c|c|c|c|}
\hline (a) Produksi. Produksi Paring (3 Bulan) & Harga Jual Kopra & & \\
\hline $2.873 .389 \mathrm{Kg}$ & Rp. $6000,-/ \mathrm{Kg}$ & $=$ & Rp.17.242.734.000 \\
\hline (b) Biaya. Biaya Produksi Paring(3bulan) & & & \\
\hline Biaya Bahan Baku & Rp. 5.747.594.600 & & \\
\hline Biaya Tenaga Kerja & 57.000 .000 & & \\
\hline Biaya Overhead Pabrik: & & & \\
\hline Biaya Depresiasi Mesin & 8.100 .000 & & \\
\hline Biaya Listrik dan Air & 14.040 .000 & & \\
\hline Biaya Bahan Bakar & 19.980 .000 & & \\
\hline Biaya Angkut & 4.500 .000 & & \\
\hline $\begin{array}{l}\text { Total Biaya Produksi Paring(3Bulan) } \\
\text { (c) Keuntungan }\end{array}$ & & $=$ & Rp.5.851.214.600 \\
\hline $\begin{array}{l}\text { Keuntungan Hasil Penjualan Paring Untuk } 3 \text { Bu } \\
\text { (Keterangan : Harga jual Paring : Rp.6000,-/Kg) }\end{array}$ & ulan & & Rp.11.391.519.400 \\
\hline
\end{tabular}
Sumber : Data Hasil Olahan

Tabel 11. Perhitungan Total Biaya Produksi Tepung Kelapa, Kopra dan Paring September-November Tahun 2016.

\begin{tabular}{|c|c|c|c|c|}
\hline Jenis Biaya & $\begin{array}{c}\text { Jumlah Biaya } \\
\text { Sept, Okt, Nov, (Rp) }\end{array}$ & $\begin{array}{c}\text { Alokasi Biaya } \\
\text { Tepung Kelapa (Rp) }\end{array}$ & Kopra (Rp) & Paring (Rp) \\
\hline Biaya Bahan Baku & $17,242,755,800$ & $5,747,594,600$ & $5,747,566,600$ & $5,747,594,600$ \\
\hline Biaya Tenaga Kerja & $981,037,110$ & $867,037,110$ & $57,000,000$ & $57,000,000$ \\
\hline $\begin{array}{l}\text { Biaya Overhead Pabrik: } \\
\text { a. Biaya Depresiasi } \\
\text { b. Biaya listrik dan }\end{array}$ & $8,100,000$ & & & $8,100,000$ \\
\hline $\begin{array}{ll} & \text { Air } \\
\text { c. Biaya } \quad \text { Bahan }\end{array}$ & $64,440,00$ & $50,400,000$ & & $14,040,000$ \\
\hline $\begin{array}{l}\quad \text { Bakar } \\
\text { d. Biaya Angkut } \\
\text { Total }\end{array}$ & $\begin{array}{c}112,403,340 \\
22,500,000 \\
18,431,236,250\end{array}$ & $\begin{array}{c}70,223,340 \\
13,500,000 \\
6,748,755,050\end{array}$ & $\begin{array}{c}22,200,000 \\
4,500,000 \\
5,831,266,600\end{array}$ & $\begin{array}{c}19,980,000 \\
4,500,000 \\
5,851,214,600\end{array}$ \\
\hline
\end{tabular}

Sumber : Data Hasil Olahan

Tabel 12. Analisis Rasio Profitabilitas September-November Tahun 2016.

\begin{tabular}{lcc}
\hline Penjualan Bersih & & Rp.85.423.455.000 \\
\hline Harga Pokok Penjualan (HPP) & & 12.788 .650 \\
Laba Kotor & Rp. 3.210.923.088 & 72.635 .235 .350 \\
Biaya Pemasaran & 13.920 .215 .076 & \\
Biaya Administrasi Umum & & 6.756 .885 .050 \\
Biaya Produksi & & 34.298 .490 .812 \\
Laba Sebelum Pajak & & 3.429 .849 .081 .20 \\
Pajak 10\% & & 30.868 .641 .730 .80 \\
Laba Setelah Pajak & & \\
Catatan Total aset PT Royal Coconut & Rp.3.532.830.400.424 \\
Airmadidi &
\end{tabular}




\section{Prespektif Pelanggan}

Pengukuran kinerja pelanggan menunjukkan penilaian pelanggan terhadap pelayanan PT. Royal Coconut Airmadidi dalam memenuhi kebutuhan dan keinginan terhadap unit-unit usaha yang ditawarkan. Dalam penelitian ini diukur dari prespektif pelanggan PT. Royal Coconut Airmadidi yaitu. Pertumbuhan pelanggan

\section{Pertumbuhan Pelanggan}

Pertumbuhan pelanggan dihitung dengan membandingkan jumlah pelanggan periode sekarang dikurangi dengan jumlah pelanggan periode lalu dibagi dengan jumlah pelanggan periode lalu yang dinyatakan dalam presentase. Berikut perhitungan pertumbuhan pelanggan PT. Royal Coconut Airmadidi bulan SeptemberNovember 2016:

$\mathrm{PP}=$

$\underline{\text { Jlh pelanggan periode sekarang-jlh pelanggan periode lalu }} \times$ $100 \%$ Jlh pelanggan periode lalu

$$
\begin{aligned}
& =\frac{50-50}{50} \times 100 \% \\
& =0.00
\end{aligned}
$$

Jumlah pelanggan pada bulan September-November 2016 adalah tetap atau sama dengan 0 (nol) atau dengan kata lain tidak ada perubahan.Namun untuk pengangkutan produksi tepung kelapa sekali pengangkutan ada sekitaran 20 fit- 40 fit atau setara dengan 13 ton- 15 ton. Sehingga dapat disimpulkan bahwa pertumbuhan pelanggan PT Royal Coconut Airmadidi stabil dimana tidak naik dan turun atau dapat dikatakan bahwa PT Royal Coconut Airmadidi masih nyaman dan percaya terhadap terhadap pelayanan PT. Royal Coconut Airmadidi.

\section{Prespektif Proses Bisnis Internal.}

Proses bisnis internal PT Royal Coconut Airmadidi dilakukan untuk mengetahui efisisensi waktu penyelesaiaian transaksi dengan memenuhi tujuan memenuhi maksud dan tujuan pelanggan. Dalam penelitian ini ada dua transaksi yang dilakukan PT Royal Coconut Airmadidi yaitu transaksi pembuatan proses produksi tepung kelapa. Kinerja proses bisnis internal diukur dengan Manufacturing Cycle Efficiency (MCE).

\section{Proses Pembuatan Tepung Kelapa}

Pembuatan produksi tepung kelapa yaitu membandingan standar waktu yang dibuat oleh PT Royal Coconut Airmadidi dengan realisasi atau bukti nyata dalam melakukan proses pembuatan tepung kelapa.

Proses pembuatan tepung kelapa dapat dilihat pada Tabel 13. Berdasarkan pada Tabel 13 dapat diketahui bahwa hasil perhitungan Mannufacturing Cycle Efficiency ( MCE) adalah sebagi berikut :

$$
M C E=\frac{86}{68}=1,27
$$

Menurut Jayanto (2009) manufacturing cycle efficiency (MCE) yang sempurna atau ideal adalah sebesar 1, dimana jika $>1$ maka proses yang dilakukan adalah efisien sedangkan $<1$ proses yang dilakukan kurang efisien atau tidak efisien. Sehingga dapat dikatakan bahwa MCE pada waktu transaksi di PT Royal Coconut Airmadidi lebih besar dari satu atau sama dengan 1,27 dimana waktu proses pengolahan tepung kelapa menunjukkan bahwa MCE lebih besar dari satu artinya proses pembuatan tepung kelapa telah berjalan efisien karena waktu realisasi lebih besar dari pada waktu standar.

\section{Prespektif Pembelajaran dan Pertumbuhan}

Pengukuran kinerja pembelajaran dan pertumbuhan terpusat pada karyawan atau sumberdaya dalam PT. Royal Coconut Airmadidi. Dalam penelitian ini ada dua kinerja yang diukur yaitu produktivitas karyawan dan retensi karyawan.

\section{Produktivitas Karyawan}

Tolak ukur yang dipakai adalah rasio produktivitas karyawan yaitu presentase perbandingan antara laba operasional dengan jumlah karyawan pada periode bersangkutan. Hasil pengukuran produktivitas karyawan PT Royal Coconut Airmadidi. Tabel 14. Hasil Perhitungan Produktivitas Karyawan PT. Royal Coconut Airmadidi Bulan Sept-Okt Tahun 2016. Tabel 14. menunjukkan bahwa bulan September 2016 pendapatan bersih setiap karyawan PT Royal Coconut Airmadidi mengasilkan Rp. 2.233.280,33 bulan Oktober Rp. 2.919.447,27 dan bulan November 2016 
mengalami kenaikan sebesar 33.488.472,152 menjadi 33.557.088,846. Sehingga, rata-rata produktivitas karyawan PT Royal Coconut Airmadidi sebesar Rp. 11.364.120,535. Produktivitas PT Royal Coconut Airmadidi dinilai baik karena mengalami kenaikan. Ini disebabkan oleh biaya-biaya yang dikeluarkan pada bulan November tahun 2016 semakin sedikit yaitu Rp. 2.632.491,478 sedangkan pendapatan yang diperoleh semakin meningkat yaitu Rp 46.344.347,720.

\section{Retensi Karyawan}

Tolak ukur yang digunakan adalah rasio retensi karyawan yaitu presentase perbandingan antara jumlah karyawan yang keluar dengan jumlah karyawan pada periode bersangkutan.
Jumlah karyawan pada tingkat retensi karyawan PT. Royal Coconut Airmadidi Bulan September-November dapat dilihat pada Tabel 15. Tabel 15. menunjukkan bahwa jumlah karyawan PT. Royal Coconut Airmadidi Bulan September-November 2016 sebesar 354 orang. Sehingga dapat diketahui bahwa tingkat retensi karyawan PT. Royal Coconut Airmadidi adalah tetap atau tidak ada perubahan. Ini disebabkan oleh karena karyawan masih merasa nyaman dengan pekerjaannya. Sehingga diharapkan PT Royal Coconut Airmadidi harus tetap mempertahankan dan meningkatkan kinerja dengan memberikan kebijakan-kebijakan yang membuat karyawan lebih merasa terjamin dan tetap bertahan seperti tambahan tunjangan (imbalan/gaji) yang akan mendorong karyawan untuk bekerja lebih baik.

Tabel 13. Proses Pembuatan Tepung Kelapa

\begin{tabular}{llcc}
\hline No & \multicolumn{1}{c}{ Waktu Proses } & Waktu Standar (menit) & Waktu Realisasi (menit) \\
\hline \multirow{2}{*}{1} & Waktu kelapa dikupas sabutnya dan & & 5 \\
2 & tempurungnya dicungkil & 8 & 5 \\
3 & Waktu menghilangkan kulit ari & 10 & 5 \\
4 & Waktu melakukan proses blanching & 10 & 15 \\
6 & Waktu proses perendaman & 10 & 5 \\
7 & Waktu kemarutan tepung kelapa & 8 & 25 \\
8 & Waktu keluarkan tengeringan & 30 & 8 \\
& Jumlah Waktu Proses & 10 & 68 \\
\hline
\end{tabular}

Sumber : PT Royal Coconut Airmadidi

Tabel 14. Hasil Perhitungan Produktivitas Karyawan PT Royal Coconut Airmadidi SeptemberNovember 2016.

\begin{tabular}{lccc}
\hline Bulan & Jumlah Karyawan & Laba Operasional (Rp) & Produktivitas Karyawan (Rp/orang) \\
\hline September & 354 & $790.581,240$ & $2.233 .280,33$ \\
Oktober & 354 & $1.033 .484,334$ & $2.919 .447,27$ \\
November & 354 & $33.891,361,606$ & $33,557,088,846$ \\
& & & $34,092,361,606$ \\
& & & $11,364,120,535$ \\
\hline
\end{tabular}

Sumber : PT Royal Coconut Airmadidi (diolah)

Tabel 15. Retensi Karyawan PT Royal Coconut Aimadidi September-November 2016.

\begin{tabular}{lccc}
\hline \multicolumn{1}{c}{ Bulan } & Jumlah Karyawan (orang) & Karyawan Yang Keluar (orang) & Retensi Karyawan (\%) \\
\hline September & 354 & 0 & 0,00 \\
Oktober & 354 & 0 & 0,00 \\
November & 354 & 0 & 0,00 \\
\hline
\end{tabular}

Sumber: PT. Royal Coconut Airmadidi (diolah) 


\section{KESIMPULAN DAN SARAN}

\section{Kesimpulan}

Berdasarkan hasil pengolahan data dan pembahasan pada bab sebelumnya peneliti menarik kesimpulan bahwa kinerja Industri Tepung Kelapa PT. Royal Coconut Kelurahan Sarongsong Satu Kecamatan Airmadidi Kabupaten Minahasa Utara ditinjau dari Balanced Scorecadyaitu prespektif keuangan sudah dapat diukur dengan baik dan sempurna karena mendapatkan keuntungan setiap bulan dari asset PT. Royal Coconut dalam status berkembang. Kinerja dari prespektif pelanggan secara umum sudah sesuai dengan yang diharapkan, hal ini dapat dilihat dari mempertahankan pelanggan setiap bulan. Pada prespektif proses bisnis internal diperoleh gambaran bahwa PT. Royal Coconut Airmadidi dalam memproduksi barangnya secara efisien dan efektif. Pada prespektif pembelajaran dan pertumbuhan dapat dilakukan dengan baik karena karyawan masih nyaman atas pelayanan dari PT. Royal Coconut Airmadidi. Dari semua prespektif dapat dinilai bahwa ukuran kinerja PT. Royal Coconut Airmadidi sudah cukup baik.

\section{Saran}

Berdasarkan kesimpulan di atas maka dapat diberikan saran untuk Industri Tepung Kelapa PT. Royal Coconut Kelurahan Sarongsong Satu Kecamatan Airmadidi Kabupaten Minahasa Utara untuk tetap mempertahanakan kinerja keuangan dari aspek penerimaan dan biaya produksi yang didapatkan. Prespektif pelanggan dari aspek pertumbuhan pelanggan tetap mempertahankan agar supaya pertumbuhan pelanggan tetap stabil. Dilihat dari prespektif bisnis internal tetap mempertahankan agar produk yang dihasilkan efektif dan efisien. Untuk prespektif pembelajaran dan pertumbuhan tetap memperthanakan kepuasan karyawan akan pekerjaan di masing-masing bidang dengan imbalan dan keseuaian kerja yang seimbang, sehingga akan memperoleh SDM yang lebih baik dan menunjang keberlanjutan perusahaan.

\section{DAFTAR PUSTAKA}

Arini agustini, 1990. Pengukuran Kinerja PT. Timuraya Tunggal Dengan Pendekatan Balanced Scorecard, (Skripsi). Fakultas Ekonomi, Universitas Katolik Atmajaya, Jakarta.

Jayanto, T. 2009. Pengukuran Kinerja Aktivitas Pada Bagian Assembling (Studi Kasus Pada PT. NIPRESS Tbk). Skripsi. Fakultas Ekonomi Universitas Atma Jaya, Yogyakarta.

Kementerian Perindustrian, 2008. Industri Hilir Kelapa Sawit Indonesia Jakarta: PT. Mitra Media Nusantara.

Kaplan, N. 2001. Analisis Balanced Scorecard Sebagai Alat Pengukur Kinerja Perusahaan (Studi Kasus Pada PT. Astra Honda Motor). Skripsi. Universitas Diponegoro Semarang.

Kaplan, N. 1990. Analisis Pengukuran Kinerja Perusahaan Dengan Metode Balanced Scorecard. (Studi Kasus Pada PT. Bank Jateng Cabang Utama Semarang). Skripsi. Universitas Diponegoro Semarang.

Kaplan, N. 2010. Analisis Pengukuran Kinerja Perusahaan Dengan Metode Balanced Scorecard. (Studi Kasus Pada PT. Bank Jateng Cabang Utama Semarang). Skripsi. Universitas Diponegoro Semarang.

Keown, 2008. Sistem Menajemen Kinerja Terintegrasi Balanced Scorecard Dengan Six Sigma Untuk Organisasi Bisnis Dan Pemerintah PT. Gramedia Pustaka Utama, Jakarta.

Rahmat, 2000. Prospek Pengelolaan Hasil Samping Buah Kelapa. Pusat Penelitian dan Pengembangan Perkebunan. Skripsi. Universitas Djuanda Bogor. 